\title{
THE STATUS OF ENGLISH IN MOROCCO: LESSONS FROM SPONTANEOUS DEBATES IN SOCIAL MEDIA
}

\author{
Abdelmajid Bouziane and Mohamed Saoudi \\ Faculty of Letters and Humanities Ben M'Sik, \\ Hassan II University of Casablanca, Morocco
}

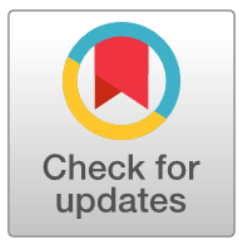

\begin{abstract}
Morocco, a multilingual country with historical and geo-political legacies, has opened a hot debate on languages recently. Within this debate, this article investigates spontaneous comments in social media on languages in Morocco, especially adopting English as a first foreign language. It aims to bring this topic to the surface and thus discuss it in the light of research on language attitudes and language awareness. To do so, it analyses the reactions to texts about the declarations by the Minister of Higher Education shared in social networks and sites. The data consisting of 2,018 comments is classified according to 12 frequent patterns whose frequencies are calculated. The findings show that most of Moroccans have positive attitudes towards English while some show opposing reactions towards French. These participants hold ambivalent opinions about the rest of languages used in Morocco; however, they tend to insist on Morocco having a clear language policy which, seemingly, prioritises the mother tongues, Arabic and Amazigh. The discussions show that some investigated reactions are mitigated as they may be illusionary.
\end{abstract}

Key words: social media, language attitudes, policy, Morocco

\section{Article history:}

Submitted: 16 August 2021

Reviewed: 22 October 2021

Accepted: 28 November 2021

Published: 30 December 2021

\section{Contributor roles:}

Conceptualization, Supervision, Methodology, Validation, Writing- review and editing, A.B. (lead); Project Administration, Data Curation, Visualization Writing - original draft M.S. (lead); Investigation, Formal Analysis A.B., M. S. (equal)

Copyright (C) 2021 Abdelmajid Bouziane and Mohamed Saoudi

This open access article is published and distributed under a CC BY-NC 4.0 International License which permits non-commercial use, distribution, and reproduction in any medium, provided the original author and source are credited. Permissions beyond the scope of this license may be available at a.bouziane@flbenmsik.ma. If you want to use the work commercially, you must first get the authors' permission.

Citation: Bouziane, A., \& Saoudi, M. (2021). The Status of English in Morocco: Lessons from Spontaneous Debates in Social Media. English Studies at NBU, 7(2), 187-208. https://doi.org/10.33919/esnbu.21.2.4

\begin{abstract}
Abdelmajid Bouziane is a professor of education at Hassan II University of Casablanca, Morocco. He has served as a project manager and participant in different national and international projects related to education. He has published widely in the areas of teaching English as a foreign language, ICT, and education in general. He serves as a peer reviewer for some international journals. His areas of interest are: TEFL, ICT in education, research methods, teachers' associations, and language policy. He has supervised several master and doctorate theses.
\end{abstract}

E-mail: a.bouziane@flbenmsik.ma

https://orcid.org/0000-0002-4138-2450

Mohamed Saoudi is a freenlance teacher of English. He earned a master's degree in Moroccan American Studies from the Faculty of Letters and Humanities Ben M’Sik, Casablanca, Morocco.

E-mail: mosaoudi7@gmail.com 
French and English are the two main foreign languages taught in Morocco in addition to the two official languages, Arabic and Amazigh. They are also used as mediums of instruction in many disciplines. The replacement of French with English has been a hot debate in Morocco over the last decade. For historical reasons, this topic has become a sensitive issue as France, through the Francophonie, tries to maintain its economic and cultural interests in Africa in general and in Morocco in particular. Recently, due to different political, economic, and social factors, a debate questioning the status of each language in Morocco came to the surface.

Specifically, this debate on the status of English in Morocco got hotter in the last decade after Minister Daoudi's various declarations. During his term in the office, the Minister of Higher Education, Lahcen Daoudi (2012-2016) never failed to call for the use of English in technology and scientific research in Morocco. He mainly declared in different official meetings that "English is the language of technology and scientific research par excellence". Later when he was addressing students in Ibnou Zohr University in Agadir, he declared that "a student who does not master English should dig his / her own grave". He even issued a circular in which he requires publishing in English as a prerequisite for doctorate viva and reasonable knowledge of English for recruitment in higher education. These calls from officials and policy makers were widely reported by the media and interpreted by their readers as a call for making of English a first foreign language. Social network sites (SNSs), especially online newspapers and websites such as Morocco World News and Hespress, made of such declarations platforms for generating long discussions about the feasibility of this project and reviving the discussions of languages in Morocco. Such social networks represent alternative options for people to express their opinions and put pressure on policy makers (Anderson, 2008). Within this framework, this study aims to analyse the comments generated in different SNSs as reactions to the Minister's declarations. It mainly examines the extent to which people are aware of the implications of adopting English as a first foreign language in Morocco. Since people are not asked to give their opinions through any type of survey, it is important to study people's spontaneous comments on the adoption of English language as the first foreign language (instead of French as some understood it!). Generally, the study explores these comments to understand the attitudes of Moroccans towards language issues in Morocco and mainly to discuss them. It addresses the following research questions: 
1. What are the attitudes of people towards adopting English as a first foreign language in Morocco?

2. What are their attitudes towards the languages in use in Morocco?

\section{Theoretical background}

This study is informed by two main frameworks that help with the answer to the research questions, namely the language policy as set by the official documents and the previous research on the attitudes of the Moroccans towards the languages in use in Morocco. The official documents and the official discourse have always insisted on the teaching of both the mother tongues and the foreign languages. The National Charter of Education and Training (COSEF, 1999) set the main guidelines of the Moroccan language policy. Lever 9, or Articles 110 to 118 in this Charter, gives cues of a language policy that boost the mastery of Arabic, encourage learning foreign languages, and call for opening to Amazigh. It urges policy makers to facilitate access to foreign languages at an early age to equip learners with necessary language skills. Later the same calls occurred in subsequent reforms such as the Emergency Plan (MoE, 2008) which provides an action plan with a timeline and a budget of implementation. Similarly, the Strategic Vision 2015-2030 (Higher Council, 2015) and the Framework Law 51.17 (Law 51.17, 2019) reiterate the earlier hopes and claims; however, the Amazigh status changed in the meantime as it gained the status of an official language in the 2011 Constitution. The optimal objective of the official documents cited thus far is to: "ensure that students at the end of high school master the Arabic language, communicate in the Amazigh language, know at least two foreign languages" as reported in the Strategic Vision 2015-2030 (Higher Council, 2015, p. 17) and reiterated in the 51.17 Law (Law 51.17, 2019 in Article 32). Recently, the New Model of Development (New Model of Development, 2021) did the same with an addition of suggesting and naming English as a foreign in vocational training institutions.

Officials and different decision makers have stressed the importance of English to the Moroccan education system. As mentioned above, the Minister of Higher Education, Lahcen Daoudi, not only raised the importance of English to technological and scientific research to Moroccan researchers but also took actions to reinforce its implementation. The current Minister, Said Amzazi, has taken actions, too. He started discussions with the US Ambassador to Morocco to strengthen English in Moroccan schools and universities 
(Hatim, 2020). He also launched in collaboration with British Council a project of 43episode radio programme that helps Moroccan learners study English (Bigo, 2021). Another strong action that boosts the presence of English and the Anglo-Saxon education orientation is the appointment of Driss Ouaouicha, a PhD holder from an American university and a former Dean, vice-President, and President of Al Akhawayn University in Ifrane which has adopted English as a medium of instruction since its creation in 1995, as a Minister Delegate to the current Minister, Said Amzazi, in charge of Higher Education and Scientific Research. This appointment has given a boost to the implementation of a fouryear Bachelor programme to replace the three-year Licence system adopted by Morocco in 2003 to align with the Bologna Process. In this new Bachelor, English is taught for four semesters to all university students in lieu of the Licence system which abolished English in the tertiary level and maintained the dominance of French (Bouziane, 2013).

In parallel with the official calls, the civil society voiced the same stance. The Rabat Center for Political and Strategic Studies issued a report which called for replacing French with English in the Moroccan system of education (Arbaoui, 2015). Similar initiatives have been taken by both official and non-official organisations as documented in a blog titled, Morocco and the English Language Debate (2018). The continuous calls by politicians to urge Moroccans to learn English to use it for international communication and scientific research have created an endless debate that started in the offline and has continued in the online world (Baker, 2013). This article analyses the online debate that followed Daoudi's declarations.

The main theory that informs this study is the one of attitudes. Language attitudes' theory is associated with people's reactions towards language policy. According to Ajzen (2005): "[a]n attitude is a disposition to respond favorably or unfavorably to an object, person, institution or event." (p. 3). The same author adds that "attitude is a hypothetical construct that, being inaccessible to direct observation, must be inferred from measurable responses" (ibid.). Thus, attitudes are interactions which reflect emotions, beliefs or/and thoughts that one does, says, acts or reacts on what others do or say. In the process of forming attitudes, it is very important to distinguish between three components of an attitude (McKenzie, 2010). The cognitive which encompasses individual's thoughts and beliefs about the world, and this might include stereotypes and prejudices; the affective which includes emotional responses towards language and it is always associated with 
kinds of verbalized or nonverbalized feelings (Eiser, 2001); and the conative which means readiness and predisposition to behave in a particular way. This study tries to infer attitudes from spontaneous reactions, triggered by the self, to an issue that interests their writers and their communities (ethnic group, family, children, relatives...).

Within the framework of attitudes, previous literature has highlighted the important status of English in Morocco. An empirical study by Bouziane (2021) documents the Moroccan university learners' enthusiasm to learn English and how they consider it a vector of their own and their country's development. She compares the views of the students who receive their education in English as a medium of instruction from private and public institutions $(n=462)$. She has found that both groups believe in the contribution of English to the development of Morocco in the areas of economic growth, academic success, scientific research and R\&D, international communication, mobility, and employability. However, unlike their public peers, the students in the private sector view English as an asset in their employability together with French. Similarly, other studies have shown that the Moroccan students hold positive attitudes towards English (Sadiqi, 1988; Bouzidi, 1989; Anderson, 2013; Buckner, 2011; Et-tahiri, 2019; Bouziane, 2020a). Such attitudes should be cautiously considered. Generally, the Moroccan students' attitudes are based on instrumental motives towards the learning of foreign languages, particularly English. The position of English at the international scene, its role in having access to updated online and print resources, attracting foreign direct investments and tourists, getting more job opportunities and promotion in jobs, and mobility are among the reasons put forward by these students in the surveys of the above-cited studies. They all show their willing to learn other languages; however, Buckner (2011) argues that the upper-class learn English to maintain their prestige while the lower-class do so to escape their low level in other languages and to seek positions as teachers of English. Importantly, the learning of foreign languages in Morocco is more determined by factors related to intrinsic motivation and social class (Buckner, 2011; Bouziane, 2020a, 2020b) than to the language policy put in place by the decision makers (Bouziane, 2020a). All these factors that contribute to the Moroccans' attitudes towards languages, and specifically towards English, are tackled in this article through their reactions to the calls of reinforcing English in the Moroccan education system. The methodology of research explains more. 


\section{Research methodology}

This study adopts netnography as a strategy of research. According to Kozinets (2019), this strategy "adapts the method of ethnography and other qualitative research practices to the cultural experiences that encompass and are reflected within the traces, networks, and systems of social media" (p. 19). Accordingly, this study tries to study the attitudes towards languages in the Moroccans' interactions in social media. Naturally, ethics are observed in this study despite their complexities in online materials. Martin \& Christin (2016) have discussed whether the online materials are public or private. They conclude that "In instances where group membership is large, easy to join and widely understood to be monitored, then there is a strong argument that information provided therein is essentially public in nature." (p. 86). The sites used for data collection have the characteristics raised by these authors. Although the Australian Statement on Ethical Conduct on Human Research (NHMRC, 2018) makes it clear that consent is required when using content from the internet, a different view limits the boundaries as to when to consider this content to be private: "The discussion on the blurred boundaries between public and private data highlighted the increasing demand by ethics boards to require consent for the use of quotes and narratives published by users online." (Maddox, 2021, p. 40). Neither quotes nor narratives are used in this study and no participant's identity is disclosed.

To study spontaneous online comments, some SNSs were identified as potential spaces in which the Moroccans are likely to discuss the Minister's declarations such as Hespress, Morocco World News (English and Arabic versions), YouTube and other less popular websites. Both Hespress and Morocco World News are two Moroccan online newspapers which contain all the components of an online newspaper such as news, culture, society, business, economy, health, opinions, and sports. The identified online websites gave people from different walks of life opportunities to express, discuss and exchange views on the issue of language. The Minister's declarations were discussed in 55 publications of different genres such as news reports, essays, assignments, analytical articles, interviews, and videos. These media publications generated 2,018 comments which were collected for this study. The data was systematically collected five days after the publication of an article or a video in the identified sites. However, it should be noted that the contents of the 55 publications are not included in the data of this study. 


\section{Data analysis}

Although netnography is widely used for big data analysis and mostly for business purposes (see for example Kozinets \& Gambetti, 2021), this strategy informs this study too. However, unlike the big data analyses which use software programmes for automated data processing, the use of a software programme in this study was impractical. The interactions came out in different scripts and languages: Standard Arabic, Darija (Moroccan dialect), French, English, Darija written in Latin scripts, codeswitching comments, or those in text messaging. Thus, they were categorised manually following these steps: (1) after reading part of the data, some patterns revealing attitudes towards languages occurred, (2) these patterns were coded and classified and as new patterns occurred, they were added to the list (3) then the frequency of each pattern was calculated and put in a graph. The comments are classified in twelve recurrent views expressed in the ongoing debate regardless of the emotional state of the people who participated in the discussion. The following list was identified:

1. English is the language of technological progress and scientific research.

2. English is an international language (lingua franca).

3. French is an outdated language.

4. Morocco should have adopted English years ago.

5. Morocco should adopt Arabic and English.

6. Morocco should adopt Amazigh and English.

7. Morocco should keep French and English.

8. French is the language of the coloniser

9. The Francophone lobby is strong in Morocco.

10. Morocco should have a clear language policy.

11. Decision makers do not take reform in education seriously.

12. Out-of- topic or irrelevant comments

The categories used in the analysis of the data are crucial to the discussion of the findings of this research. They are used for two purposes. The first is purely methodological; they show the recurrent patterns that are expressed in these comments and help with their grouping. The second is to work out attitudes from the frequencies of the expressed patterns. 


\section{Findings}

As mentioned above, this study aims to analyse the attitudes of the Moroccans towards adopting English as a first foreign language and, by the same token, their attitudes towards languages in use in Morocco as revealed in their interactions in the SNSs. The comments show that most commentators hold positive attitudes towards English as the following figure shows:

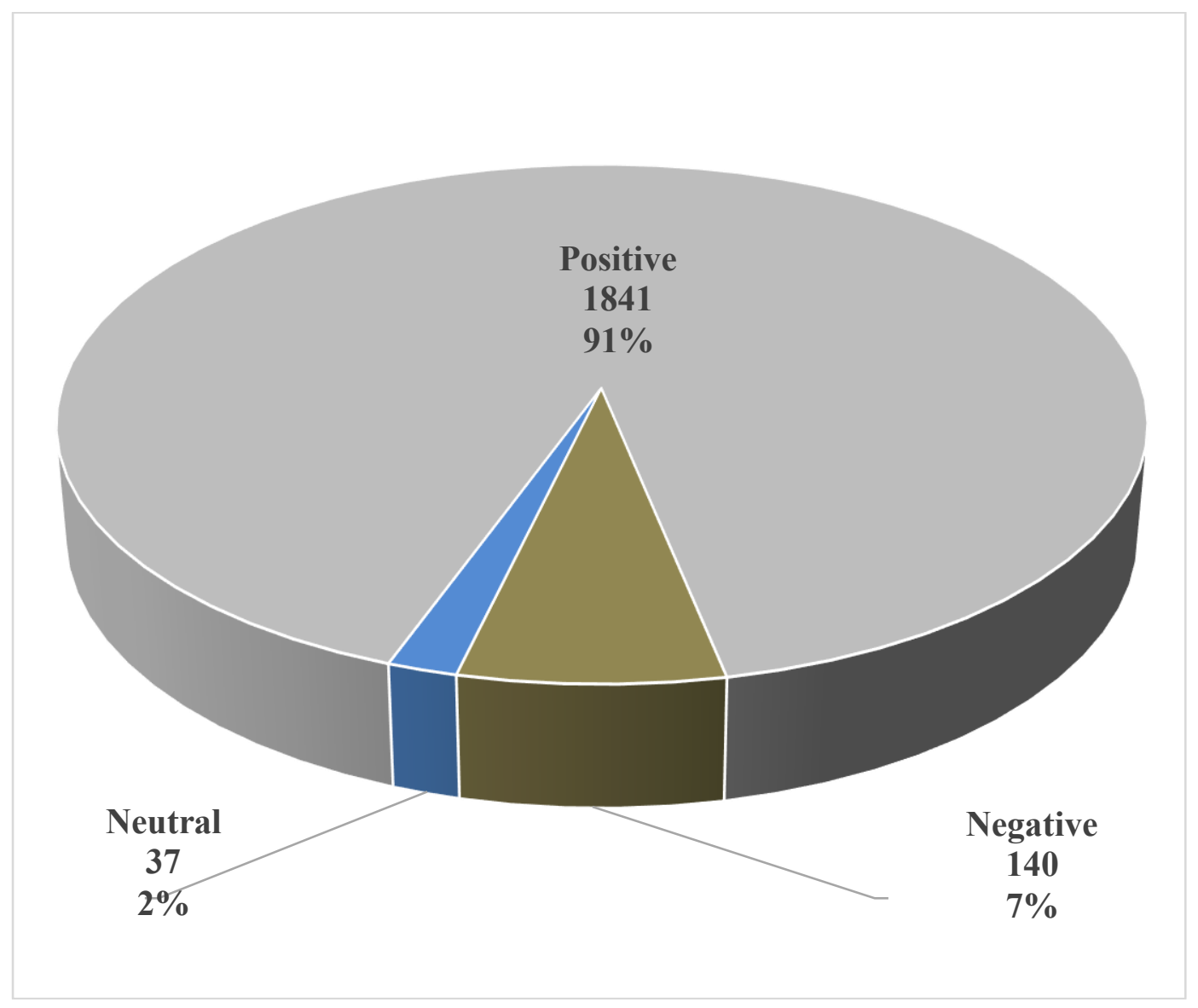

Figure 1. Attitudes towards English

Figure 1 shows that the highest number of comments carries positive attitudes towards English in Morocco. However, these people used different ways to voice their positive attitudes. In some comments, people would show their full agreement with the Minister or would urge the decision makers to act, or else would claim that English is useful for development, technology, scientific research, tourism, or economic growth, etc. They demonstrate implicitly and explicitly different levels of awareness regarding the issue of language policy in Morocco. In a wider perspective, Figure 2 illustrates the twelve arguments which represent the attitudes of people towards language issues in Morocco. 


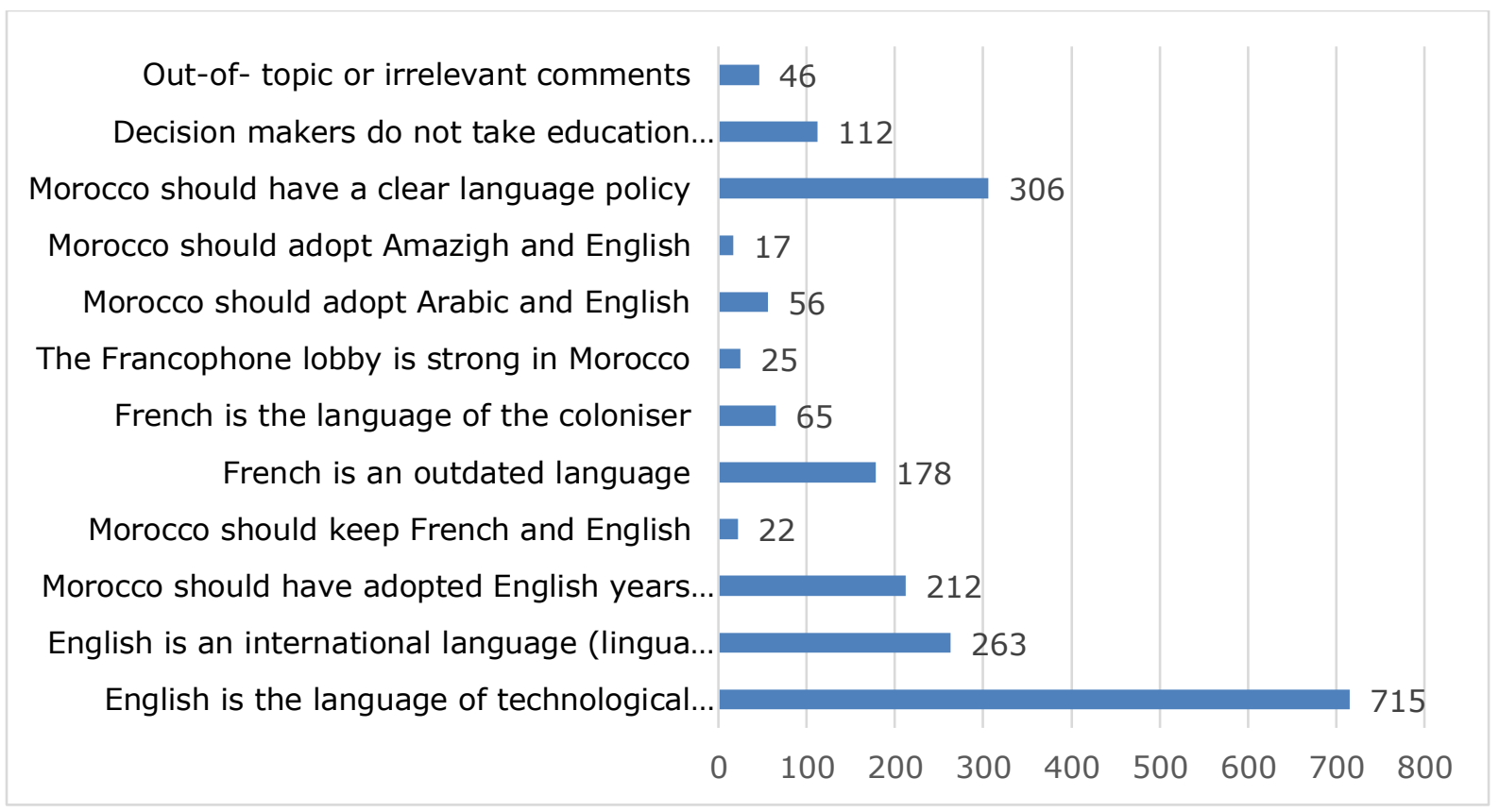

Figure 2. The frequency of the twelve patterns in SNS comments

Most comments in Figure 2 have focused on English (59\%). The Moroccans share the idea that English is important for technology and scientific research, international communication and that Morocco should act quickly and adopt English. Noticeably, this focus comes at the detriment of other languages. Very few people have chosen the combination of another language with English as they show reservation in adopting any of the other languages in use in Morocco, namely Arabic, Amazigh, or French. French tends to be the least preferred language by the commentators as they not only refuse to keep it in addition to English but they consider it to be outdated and would like to reduce its dominance in Morocco. Although the comments were on foreign languages, the commentators did not fail to raise the issues related to the official languages and to widen the discussion to include language policy and education reform.

The commentators have discussed many aspects that provide adequate answers to the research questions. First, the results show that there is a significant proportion of Moroccans who hold positive attitudes towards adopting English while others maintain negative attitudes towards the status of French in Morocco. Second, many respondents back up the priority of promoting the mother tongue before adopting a foreign language. Third, some comments reflect a certain knowledge about language policy. Finally, a close look at the comments reveals some interesting facts. It shows that the frequency of comments is closely related to the language of the text and the popularity of the website. 
Texts written in Arabic stimulated more reactions than those written in other languages. Hespress generated most interactions; for example, eleven articles generated 1,482 comments (73.4\%) among which the top ones received 244 and 205 comments. The comments in English seem well thought and their writers are aware of the language policy in place. Interactions in French are rare and the SNSs in French that deal with language issues seem almost inexistent.

\section{Discussion}

The findings of this research bring to the fore some interesting issues related to the attitudes towards languages and the languages in use in Morocco. They pave the way for further discussions that will clarify some misconceptions prevailing in the online comments.

\section{Discussions in Social network websites}

Recently, the SNSs have become an area of research as they have democratised information. They offer alternative platforms to people to react to areas of their interests. They sometimes serve as a means of putting pressure on policy makers to act in accordance with recurrent views and attitudes. In the case of this study, the articulated views about foreign languages, and particularly about English, have helped to bring the attitudes the Moroccans hold towards the issues of language policy offline to the online environment (Steinert-Threlkeld et al, 2015). Being spontaneous, these views must voice their producers' opinions as Hampton, Shin, \& Lu (2017) confirm Hampton's (2015) persistent contact and pervasive awareness when they write: "Social media increasingly make ties from offline contexts persistent online and make awareness of the opinions, interests, and activities of these ties pervasive" (p. 1104). To confirm their pervasive awareness which provides "multiplexity, transitivity, and social presence" (Hampton, 2015 , p. 12) and escape the fear of voicing an opposing view in face-to-face settings or the spiral of silence as termed by Hampton et al. (2014), most commentators use nicknames that are unlikely to disclose their identities. Such a framework of keeping in touch despite distances and voicing opinions online with more freedom informs the dynamism of discussions in the investigated SNSs in this study. The sequence of the views is far from being a thread of discussion. Accordingly, instead of interacting with the other 
members' comments in the studied SNSs, the commentators have used the online space of discussion like a bulletin board in which they put up their opinions without drawing on previous postings or even referring to them. In addition, many postings are not related to the text on which they comment. The only instances in which sequential interactions occurred are those in which language ideologies and conflicts are involved.

\section{Attitudes towards English}

It is not surprising that many people consider English the key to success and fame (Deng, 2015). Moroccans are no exception. Their comments in SNSs reveal that they view English as a passport to digital and technological revolution in many industries and sectors. Quite similar views and inclination to English are confirmed by Moroccan youth ( $\mathrm{n}=1,211$ aged between 15 and 25) (British Council, 2021). The Moroccans tend to believe that shifting language will be a leading key to economic growth. However, there is no evidence that shows that English is distinct from other languages and thus has an impact on economic development. The rise of English and its widespread might make some illusionary links between the economic growth and the language itself. The measurement of the impact of languages especially English on economic development is too complex (Coleman, 2011, TESOL Quarterly, 2002 inter alias). Therefore, the findings are not based on solid evidence that English directly contributes to the development of a particular country. Some studies such as Jain (2011), Grin (2013), and Laitin \& Ramachandran (2014), to cite a few, show that English plays a minor role in country development and economic growth.

The main claim that has been put forward in the findings is that of English being a language of technological progress and scientific research. This claim should be taken with care, however. Montgomery (2013 ) explains why some people think that English is the language of scientific and academic research. He argues that researchers who use English are more advantageous than those who use their native languages. English is crucial for scientists and academics to have access to material written or published in English. In fact, Bouziane (2021) reviews some bibliometric studies on the scientific publications in English in the domains that Morocco prioritises and has found that their percentages range from $90 \%$ to $100 \%$. For example, among the publications on COVID$19(19,991$ publications by both native and non-native speakers $)$ that appeared from 
December 2019 to June 2020, 93.8\% are in English (Kumara, Kumar, \& Vinay, 2021). Therefore, those who do not master English may find it difficult to catch up with the rapid progress of research. Regardless of the importance of English in the field of scientific research, some countries managed to develop a long tradition in scientific research without using English. The Royal Society (2011) predicted the rise of China's, together with other countries', contribution to "the increasingly multipolar scientific world" (p. 5) and thus it might surpass the UK in the coming years. Similarly, Deng (2015) claims that Germany, Japan, China, and Russia are some countries that have developed long traditions in scientific research without depending on English as a crucial language for the development of their countries. Therefore, it remains quite fallacious to claim that if policy makers adopt English, Morocco will join the leading countries in scientific research.

English not only has dominated international scientific publications but also has established itself as a universal language (Bidlake, 2008). The wide spread of English as the language of international communication has an impact on their perception of the English as it is expressed in the comments under focus. Nevertheless, it is not practical to implement a language because it is a lingua franca (House, 2003).

\section{Attitudes towards French}

Most comments about French emanate from affective attitudes which are mostly voiced in a resentful tone. These comments express the view of the Moroccans who think that French is an outdated language of the coloniser. Such an attitude can be explained in the light of the state of alienation (Cox, 1998) as people who do not master French feel they are excluded (Bullock, 2014). Besides the state of alienation, ideological affiliations play an important role in the construction of attitudes. Ideology is a major factor in shaping people's opinions about a particular subject and, thus, attitudes are the reflection of these opinions (Wortham, 2001). The claims in some comments that raise that French is the language of laicism or that French is not Morocco's national language reflect some attitudes that prevail in the society about the status of French in Morocco as some people think it sustains social class discrimination. Within the framework of ideology, the Moroccans' preference of English to French may stem from the status of both languages in Morocco and worldwide. While French is directly associated with the coloniser in 
Morocco (Buckner, 2011; Chakrani \& Huang, 2014; Ben Haman, 2021 inter alias), Coleman (2010) describes English as a neutral language.

In this same vein, pan-Arabists usually believe that there is a francophone conspiracy against the development of Arabic and, by extension, of the country that uses it (Ives, 2004). However, these arguments seem too simplistic if seen from a macro or institutional perspective. There are many realistic factors which if put together would dictate the language choice in Morocco. These factors include the economic dependence of Morocco on France as a first economic partner, the duplication of its education system, the historical relations between the two countries, adopting French as a language of business in Morocco, and the insufficient logistics to shift from French to English. All these elements make it too difficult for Morocco, at least in the coming years, to shift its interest from French to English or even develop its official languages to compete with the leading languages.

\section{Language and identity}

Different attitudes towards languages in Morocco and their relation to identities are full of intricacies that may be beyond this article. However, identities shape language choices of individuals as well as those of communities. The findings in this study echo the three trends of language identity advocated in Morocco as identified by (Benmamoun, 2001, p. 95) but with softened discourse. A trend that claims adopting classical Arabic only and eliminating French especially in the education system still prevails in some comments. Unlike in 2001, these advocates either have become advocates of English or have softened their discourse. Another trend that promotes Amazigh as a component of the Moroccan identity has been recurrent. Apart from a few radicals (see below), this trend claims generalising the Amazigh language in all schools and granting this language its real status of an official language (see further discussion below). The last trend that started from the premises that "the question of language policy should be framed in pragmatic developmental terms" (Benmamoun, 2001, p. 104) is the most prevailing. The advocates of this trend consider French or another foreign language a means of maintaining Morocco's interests with other countries and keeping it abreast of technological and research updates. It seems that this openness to foreign languages has outweighed English over French. 
As mentioned above, the proponents of Arabic believe that there is a conspiracy against Arabic and claim that Arabic should be implemented properly. Although the issue of Arabisation has not been directly raised in the comments, it has its share in the slowdown of the Moroccan education system because it has not been appropriately implemented (Boutieri, 2016). The status of Arabic is far more complex because for Moroccans "Arabic is the language which represents them and with which they project their identity in the world. This being the case, however, reality shows the reverse." (Loutfi, 2020). Despite so many publications on this issue (see for example Ennaji, 2005), this area of Arabic, identity and language choice needs further research.

Advocates of the Amazigh have shown diverse attitudes. Some see the focus on Arabic and Arabisation as a continuity of marginalising the Amazigh language. They think that the policy makers are not serious in the implementation of this language (Zouhir, 2014; Alalou, 2018). Realistically, Morocco does not suffer from the lack of a comprehensive vision of the role of Amazigh; rather, it suffers from the lack of adequate human resources and infrastructure for its gradual implementation and, especially, of more support from the government and the Moroccan youth who relate success to English and French (Schwed, 2017). Some calls for revitalising the Amazigh are launched (Boukous, 2011; Idhssaine, 2021) especially for the sake of preserving it for future generations (El Kirat, 2008). "Amazigh activists are asking the government and the parliament to enact further laws for the implementation of their language" Jaafari (2019, p. 129) stated. Other advocates of Amazigh see in Arabic an alien language and they prefer the adoption of English only as an alternative to Arabic. More radically, a few comments in favour of Amazigh are loaded with hateful views towards Arabic language. The writers of these comments consider Arabic the language of the "coloniser" which must be abolished from being used in "Amazigh land", meaning free people's land.

Adding English to French is another argument. Advocates of this trend argue that Morocco has long relations with France and other French-speaking countries in Africa. They consider adding English will enable Morocco to improve its relations with other English-speaking countries, especially with the new interest in Africa after Morocco's renewal of diplomatic and political relations with African countries (Charai, 2016). Generally, the Moroccans' attitudes towards foreign languages are triggered by instrumental motives (Buckner, 2011; Bouziane, 2020a and 2020b, inter alias). 


\section{Language policy and language conflicts}

Many other comments express clear criticism to the policies of the state. They put the blame on the role of the state in designing inaccurate policies. They raise that the real problem in Moroccan educational system is the lack of the necessary tools for the implementation of an appropriate language policy. These people argue that English or any other language alone cannot improve the educational system and develop the economy of the country. They believe that language is just a minor factor in solving the problem (Laitin \& Ramachandran, 2014). They think that the problem of language cannot be solved unless Moroccan officials consider the problem of designing an effective language policy to be a priority. In fact, Morocco needs a formalised policy which makes the teaching of languages coherent together with concrete mechanisms of implementation of this policy (Bouziane, 2018).

Strikingly, the investigated comments show that the Moroccans involved in this study tend to adhere more to an either-or than to a both-and perspective regarding languages. They failed to show an attitude of adopting the existing languages from a complementary stance. Their comments tend to reveal that an introduction of a language in the Moroccan linguistic scene should take place at the detriment of another existing language. For example, they failed to see that adding English to other existing languages is a source of empowerment and that all the languages should be welcome. Kachoub (2021), through the frequent use of English in the ads, considers that "in Morocco these four languages [Amazigh, Arabic, French, and English] do not seem to be at odds with one another, but rather to be used in complementary ways." (p. 231). She also considers that English is spreading non-formally at a large scale in Morocco and thus it is becoming an additional language.

\section{Conclusion}

This study started with the premise of investigating the Moroccans' attitudes towards the issue of languages via their comments in SNSs. The purpose of investigating these comments is to check whether Moroccans are aware of the complexity of the issues related to language policy or they hold impressionistic arguments that need more refinements. The findings of the study show that most Moroccans who commented on the 
online materials under study hold positive attitudes towards English. The arguments put forward to implement it in the education system, in lieu of French, evolve round English having an important role in boosting technological progress and scientific research, providing opportunities of employability and international openings. However, other languages have been raised, too. The advocates of Arabic or Amazigh did not fail to voice their worries about their respective language preference. The language that received the least preference, and most criticism, is French. The discussions of the findings have mitigated many of the arguments adopted by the commentators. Such arguments have been shown to be founded on impressionistic views that need further scrutiny. The beliefs that English is the key to development, and implicitly to boost the quality of the education system, may be illusionary. The Moroccans need to benefit from experiences in other countries and from the re-introduction of French over the last years in the Moroccan system to replace Arabic that had been implemented through Arabisation for decades.

\section{References}

Ajzen, I. (2005). Attitudes, Personality, and Behavior. Open University Press.

Alalou, A. (2018). The question of languages and the medium of instruction in Morocco. Current Issues in Language Planning, 19(2), 136-160. https://doi.org/10.1080/14664208.2017.1353329

Anderson, B. D. (2008). How Social Networks Influence Attitudes: Social and Informational Effects of Attitude Heterogeneity and Arguments. University of Minnesota Digital Conservancy. http://purl.umn.edu/45635

Anderson, C. (2013). "I Talk It and I Feel It": Language Attitudes of Moroccan University Students. [Unpublished BA Thesis ]. Swarthmore College. http://hdl.handle.net/10066/12511

Arbaoui, L. (2015, May 28). Moroccan Think Tank Calls for English to Replace French in Schools. Morocco World News. Retrieved from https://www.moroccoworldnews.com/2015/05/159494/moroccan-think-tankcalls-for-english-to-replace-french-inschools?fb comment id=738273959607686 1848195685282169

Baker, S. (2013). Conceptualising the use of Facebook in ethnographic research: as tool, as data and as context. Ethnography and Education, 8(2), 131-145.

https://doi.org/10.1080/17457823.2013.792504 
Ben Haman, O. (2021). The Moroccan education system, dilemma of language and thinktanks: the challenges of social development for the North African country. The Journal of North African Studies, 26(4), 709-732. https://doi.org/10.1080/13629387.2019.1711061

Benmamoun, E. (2001). Language identities in Morocco: A historical overview. In Studies in the Linguistic Sciences, 31(1), 95-106.

http://hdl.handle.net/2142/9536

Bidlake, E. (2008). Whose Voice Gets Read? English as the International Language of Scientific Publication. E-pistime, 1(1), 3-21. http://research.ncl.ac.uk/episteme/issues/issue01/contents/e-pisteme\%20Vol.1(1)\%20\%20Erin\%20Bidlake\%20(Full\%20Text).pdf

Bigo, C. (2021, July 26). SNRT : “English Time”, un programme radio pour apprendre l'anglais. https://telquel.ma/2021/07/26/snrt-english-time-un-programmeradio-pour-apprendre-langlais 1729908

Boukous, A. (2011). Revitalizing the Amazigh Language: Stakes, Challenges, and Strategies. [K. Bensoukas Trans.]. Institut Royal de la Culture Amazighe.

Boutieri, C. (2016). Learning in Morocco. Language Politics and the Abandoned Educational Dream. Indiana University Press.

Bouziane, A. (2013). Beyond gender: Is English becoming exclusive in Morocco? In Z. Abdellatif, \& A. Badr (Ed.), Gender Issues in Language Education. Language Education for Learners with Special Needs (pp. 99-103). Moroccan Association of Teachers of English (MATE).

Bouziane, A. (2018). L'enseignement des langues au Maroc : état des lieux et perspectives. [The teaching of languages in Morocco: State-of-the art and future prospects] Bassamat, 08, 27-52.

Bouziane, A. (2020a). Moroccan Students' Attitudes Towards Local and Foreign Languages: The Role of Self-Directed and Language Policy Forces. English Studies at NBU, 6(2), 295-320. https://doi.org/10.33919/esnbu.20.2.7

Bouziane, A. (2020b). Linguistic diversity in the Moroccan education system: (un)equal opportunities. In S. El Azhar, Plural Morocco: Multiculturalism and Identity (pp. 40-54). Faculty of Letters and Humanities Ben M'Sik, Hassan II university of Casablanca.

Bouziane, F. Z. (2021). The Role of Languages in the Development of Morocco: The Case of English. [Unpublished MBA thesis]. SIST Casablanca and Cardiff Met University. 
Bouzidi, H. (1989). Language attitudes and their implications for education: Morocco as a case study. University of Glasgow. [Unpublished doctoral dissertation]. http://theses.gla.ac.uk/5371

British Council. (2021). Shift to English in Morocco. The British Council. https://www.britishcouncil.ma/en/shift-english

Buckner, E. S. (2011). The Growth of English Language Learning in Morocco: Culture, Class, and Status Competition. In A. Al-Issa, \& L. S. Dahan, Global English and Arabic: Issues of Language, Culture, and Identity (pp. 213-252). Peter Lang.

Bullock, S. ( 2014). Language Ideologies in Morocco. Anthropology Department Honors Papers, Paper 11. http://digitalcommons.conncoll.edu/anthrohp/11

Chakrani, B., \& Huang, J. L. (2014). The work of ideology: examining class, language use, and attitudes among Moroccan university students. International Journal of Bilingual Education and Bilingualism, 17(1), 1-14. https://doi.org/10.1080/13670050.2012.718319

Charai, A. (2016, November 9). Why Morocco Is Investing in Africa. The National Interest. http://nationalinterest.org/feature/why-morocco-investing-africa18350 ?page $=$ show

Coleman, H. (2010). The English Language in Development. The British Council.

Coleman, H. (Ed.). (2011). Dreams and Realities: Developing Countries and the English Language. The British Council.

COSEF. (1999). Charte Nationale d' Education et de Formation [The National Charter of Education and Training]. Coimbra Group ASBL. https://www.coimbragroup.eu/tempus/Docs/charte fr.pdf

Cox, J. (1998). An Introduction To Marx's Theory of Alienation. International Socialism Journal, 79, 41-62. http://pubs.socialistreviewindex.org.uk/isj79/cox.htm

Deng, B. (2015, JAN 6). English is the Language of Science. That's lousy luck for scientists in most of the world. Slate.

http://www.slate.com/articles/health and science/science/2015/01/english is the language of science $u$ s dominance means other scientists.html

Eiser, J. R. (2001). Social Psychology: Attitudes, Cognition and Social Behaviour (8 ed.). Cambridge University Press. 
El Kirat, Y. E. (2008). Bilingualism, Language Teaching, Language Transmission and Language Endangerment: The Case of Amazigh in Morocco. In T. Graaf, N. Ostler, \& R. Salverda, Proceedings of the FEL XII (pp. 24-27). Fryske Akademy, It Aljemint, Ljouwert/Leeuwarden, the Netherlands.

Ennaji, M. (2005). Multilingualism, Cultural Identity, and Education in Morocco. Springer.

Et-tahiri, Y. (2019). Linguistic Attitudes of Moroccan University Students. [Unpublished Master Thesis]. Faculty of Arts and Humanities Ben M'Sik, Hassan II University of Casablanca

Grin, J.-L. A. (2013). Language in Economic Development: Is English Special and is Linguistic Fragmentation Bad?. In E. J. Seargeant, English and Development Policy, Pedagogy and Globalization (pp. 243-266). Multilingual Matters. https://doi.org/10.21832/9781847699473-015

Hampton, K., Rainie, L., Lu, W., Dwyer, M., Shin, I., \& Purcell, K. (2014). Social Media and the 'Spiral of Silence.'. Pew Research Center.

http://www.pewinternet.org/2014/08/26/social-media-and-the-spiral-ofsilence

Hampton, K. N. (2015). Persistent and Pervasive Community: New Communication Technologies and the Future of Community. American Behavioral Scientist, 60(1), 101-124. https://doi.org/10.1177/0002764215601714

Hampton, K. N., Shin, I., \& Lu, W. (2017). Social media and political discussion: when online presence silences offline conversation. Information, Communication \& Society, 20(7), 1090-1107. https://doi.org/10.1080/1369118X.2016.1218526

Hatim, Y. (2020, July 14). US Ambassador to Morocco Discusses English Teaching With Minister Amzazi. https://www.moroccoworldnews.com/2020/07/309942/usambassador-to-morocco-discusses-english-teaching-with-minister-amzazi

Higher Council. (2015). For a School of Equity, Quality and Promotion: A Strategic Vision of Reform 2015-2030. Higher Council for Education, Training, and Scientific Research.

Hoare, R. (2001). An integrative approach to language attitudes and Identity in Brittany. Journal of Sociolinguistics, 5(1), 73-84. https://doi.org/10.1111/1467$\underline{9481.00138}$

House, J. (2003). English as a Lingua Franca: A Threat to Multilingualism? Journal of sociolinguistics, 556-578. https://doi.org/10.1111/j.1467-9841.2003.00242.x 
Idhssaine, A. (2021). Moroccan Language Policy and the Amazigh Language Revitalisation: Implications for Amazigh Ethnolinguistic Vitality. [Unpublished doctoral dissertation]. Faculty of Letters and Human Sciences, Hassan II University of Casablanca, Morocco.

Ives, P. ( 2004). Language and Hegemony in Gramsci. Pluto Press.

Jaafari, T. (2019). Language Debates and the Changing Context of Educational Policy in Morocco. Journal of Global Initiatives: Policy, Pedagogy, Perspective, 14(2), 125142. https://digitalcommons.kennesaw.edu/igi/vol14/iss2/9

Jain, T. (2011). Common tongue: The impact of language on economic performance. MPRA Paper No. 34423. Munich Personal RePEc Archive. http://mpra.ub.unimuenchen.de/34423

Kachoub, B. (2021). English in the expanding circle of Morocco: Spread, uses, and functions. Simon Fraser University . [Unpublished doctoral dissertation]. http://summit.sfu.ca/item/21136

Kozinets, R. V. (2019). Netnography: The essential guide to qualitative social media research. Sage. https://doi.org/10.4324/9781003001430-2

Kozinets, R. V., \& Gambetti, R. (2021). Netnography Unlimited: Understanding Technoculture Using Qualitative Social Media Research. Routledge. https://doi.org/10.4324/9781003001430

Kumara, S. U., Kumar, B. T., \& Vinay, R. S. (2021). Research productivity on COVID-19: A Bibliometric approach. Library Philosophy and Practice (e-journal). https://digitalcommons.unl.edu/libphilprac/5461

Laitin, D., \& Ramachandran, R. (2014). Language Policy and Economic Development. American Political Science Review, 110(3), 457-480.

https://doi.org/10.1017/S0003055416000265

Law 51.17. (2019). Loi-cadre $n^{\circ}$ 51-17 relative au système d'éducation, de formation et de recherche scientifique [Framework Law No. 51-17 on the education system, training and scientific research]. Government of Morocco. Retrieved August 2, 2021, from http://www.aneaq.ma/wp-content/uploads/2020/12/Loi-Cadre51.17-Vr.Fr.pdf

Loutfi, A. (2020). The Status of Mother Tongues and Language Policy in Morocco. The International Journal of Applied Language Studies and Culture, 3(2), 1-10. https://doi.org/10.34301/alsc.v3i2.27 
Maddox, A. (2021). Netnography to Uncover Cryptomarkets. In R. V. Kozinets, \& R. Gambetti, Netnography Unlimited: Understanding Technoculture Using Qualitative Social Media Research (pp. 25-43). Routledge. https://doi.org/10.4324/9781003001430-3

Martin, J., \& Christin, N. (2016). Ethics in cryptomarket research. International Journal of Drug Policy, 35, 84-91. https://doi.org/10.1016/j.drugpo.2016.05.006

McKenzie, R. M. (2010). The Social Psychology of English as a Global Language Attitudes, Awareness and Identity in the Japanese Context. Springer.

MoE. (2008). Rapport Résumé du Plan d'Urgence. Rabat: Ministry of Education. Retrieved August 2nd, 2021, from https://planipolis.iiep.unesco.org/sites/default/files/ressources/morocco prog ramme urgence rapport resume.pdf

Montgomery, S. L. (2013 ). Does Science Need a Global Language? English and the Future of Research. University of Chicago Press. https://doi.org/10.7208/chicago/9780226010045.001.0001

Morocco and the English Language Debate. (2018, July 31). http://riadzany.blogspot.com/2018/07/morocco-and-english-languagedebate.html

New Development Model (2021). The New Development Model: Releasing Energies and Regaining Trust to Accelerate the March of Progress and Prosperity for All. Rabat: The Special Commission on the New Development Model. https://www.csmd.ma/documents/CSMD Report EN.pdf

NHMRC. (2018). National Statement on Ethical Conduct in Human Research 2007 (Updated 2018). National Health and Medical Research Council. Retrieved from https://www.nhmrc.gov.au/about-us/publications/national-statement-ethicalconduct-human-research-2007-updated-2018

Sadiqi, F. (1988). The Spread of English in Morocco. In A. Zaki, A. Boumoussa, M. Najbi, \& S. Mehdi (Ed.), ELT in Morocco: Directions for the Nineties (pp. 69-79). Moroccan Association of Teachers of English.

Schmidt, R. (2010). Attention, awareness, and individual differences in language learning. Proceedings of CLaSIC 2010 (pp. 721-737). National University of Singapore. 
Schwed, J. (2017). The Power Dynamics of Language: An Analysis of the Positionality of Amazigh Language in Morocco. Independent Study Project (ISP) Collection. https://digitalcollections.sit.edu/isp collection/2632

Stebbins, R. A. (2001). Exploratory research in the social sciences. Sage. https://doi.org/10.4135/9781412984249

Steinert-Threlkeld, Z. C., Mocanu, D., Vespignani, A., \& Fowler, J. (2015). Online social networks and offline protest. EPJ Data Science 4(19), 1-9. https://doi.org/10.1140/epjds/s13688-015-0056-y

Svalberg, A. M.-L. (2009). Engagement with Language: Developing a Construct. Language Awareness. Language Awareness, 242-258. https://doi.org/10.1080/09658410903197264

TESOL Quarterly. (2002). Special topic issue: Language and Development. TESOL Quarterly, 36(3).

The Royal Society. (2011). Knowledge, Networks and Nations: Global scientific collaboration in the 21st century. https://royalsociety.org//media/Royal Society Content/policy/publications/2011/4294976134.pdf

Wortham, S. (2001). Language Ideology and Educational Research. Linguistics and Education, 12(2), 253-259. https://doi.org/10.1016/S0898-5898(01)00055-9

Zouhir, A. (2014). Language Policy and State in Morocco: The Status of Berber. Digest of Middle East Studies, 23( 1), 37-53. https://doi.org/10.1111/dome.12039 